\title{
Enhanced detection of Enterocytozoon salmonis (Microspora), an intranuclear microsporean of salmonid fishes, with the Warthin-Starry stain combined with hematoxylin and eosin
}

\author{
M. L. Kent*, V. Rantis, J. W. Bagshaw, S. C. Dawe
}

Biological Sciences Branch, Department of Fisheries and Oceans, Pacific Biological Station, Nanaimo, British Columbia, Canada V9R 5K6

\begin{abstract}
Enterocytozoon salmonis, an intranuclear microsporean of salmonid fishes, is often difficult to visualize by light microscopy. In paraffin sections stained with hematoxylin and eosin $(\mathrm{H \& E})$, the parasite appears as a light staining sphere within the nucleus, and can easily be confused with nucleoli or nuclear vacuoles. Furthermore, the spores of E. salmonis are very small and do not form large aggregates, and thus are not easily identified in sections or wet mounts. The Warthin-Starry stain combined with H\&E dramatically enhances the detection of the parasite in tissue sections. Using this method, prespore stages stain light brown to black, and spores stain dark brown or black.
\end{abstract}

KEY WORDS: Microsporea - Enterocytozoon - WarthinStarry stain

The genus Enterocytozoon (Enterocytozooidae: Apansporoblastina) contains 2 described species, 1 from humans and 1 from fishes. E. bieneusi infects enterocytes of humans with AIDS (Weber et al. 1994). E. salmonis infects the nuclei of immature leucocytes of salmonid fishes and is associated with anemia (Elston et al. 1987) and lymphoproliferation (Hedrick et al. 1990. Morrison et al. 1990). We often see the parasite within the nuclei of plasmablasts from chinook salmon Oncorhynchus tshawytscha with plasmacytoid leukemia (Kent et al. 1990). Most reports of E. salmonis have been from chinook salmon from the Pacific region

·E-mail: kentm@pbs.dfo.ca of North America. The organism has also been found in rainbow trout $O$. mykiss in France (Chilmonczyk et al. 1991), and we have detected E. salmonis in paraffin sections of coho salmon $O$. kisutch from Chile. A similar microsporean infects the nuclei of leucocytes of lumpfish Cyclopterus Iumpus, and also has been associated with lymphoproliferation (i.e. lymphosarcoma) (Mullins et al. 1994).

The spores of Enterocytozoon species are very small (about 1 to $2 \mu \mathrm{m}$ ) and do not form large aggregates (e.g. in xenomas). Therefore, detection of these parasites in sections using routine stains such as hematoxylin and eosin (H\&E) or in wet mount preparations is difficult. E. salmonis is particularly difficult to detect in histological sections because prespore stages appear as light staining spheres within the nucleus and can easily be confused with nucleoli or nuclear vacuoles.

The Warthin-Starry stain, a stain usually used to visualize certain bacteria, has been recommended by a number of researchers for the detection of $E$. bieneusi in intestinal biopsies (Field et al. 1993a, b). We have found that the Warthin-Starry stain combined with Harris' H\&E (regressive method) (see Appendix) is an excellent method for enhancing the contrast between E. salmonis and nuclear material (Fig. 1). Using this method, prespore stages stain brown, spores are dark brown or black, while nucleoli retain their characteristic basophilic (blue) staining and nuclear spaces remain unstained. 

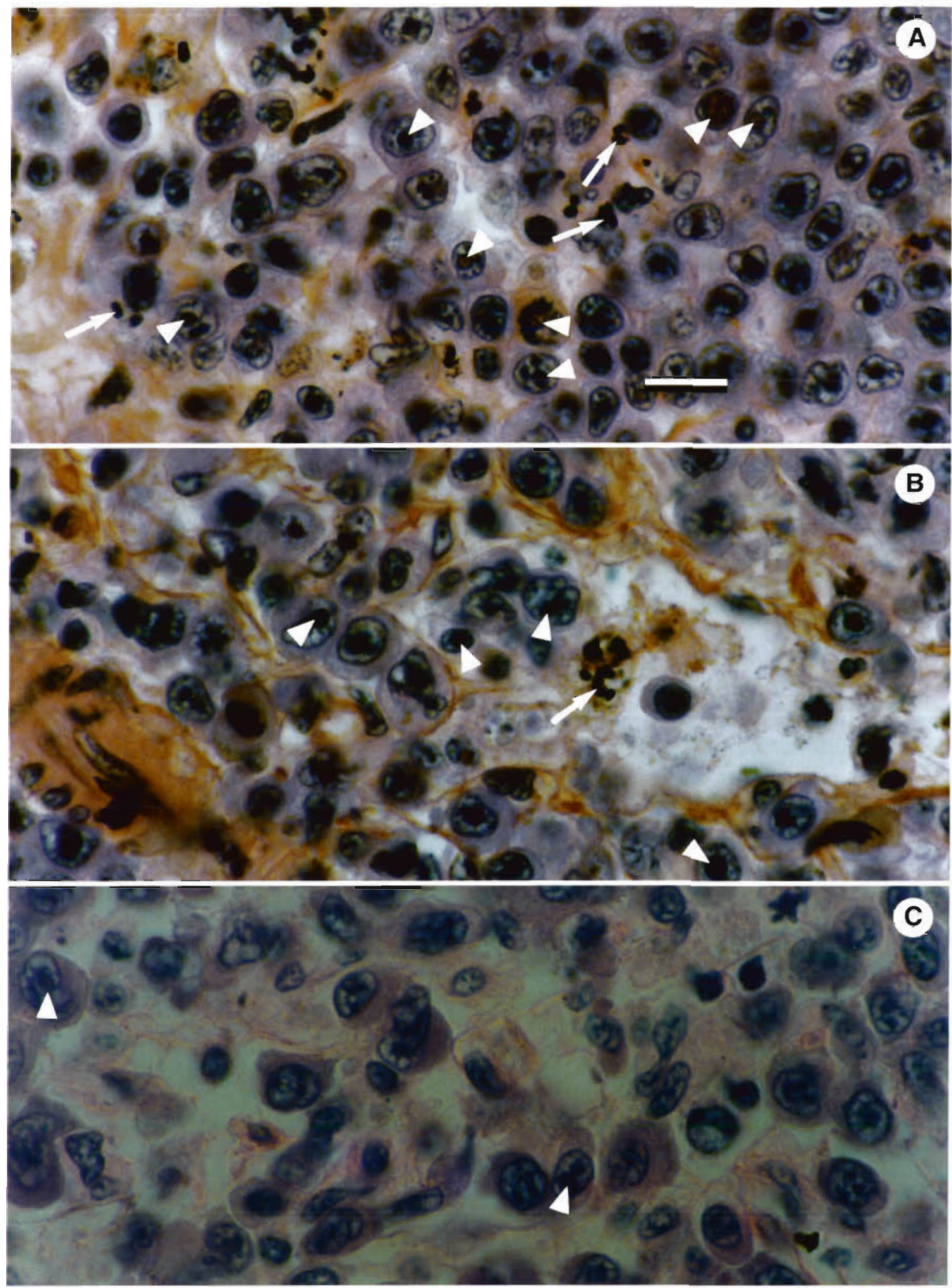

Fig. 1. Oncorhynchus tshawytscha. Plasmablasts infected with Enterocytozoon salmonis in retrobulbar tissue. All photographs are from the same area. Note that many spores (arrows) and more prespore stages (arrowheads) are visible with the WarthinStarry/H\&E (A and B), compared to sections stained only with $\mathrm{H} \& \mathrm{E}(\mathrm{C})$. Scale bar $=10 \mu \mathrm{m}$ 
Appendix. Warthin-Starry stain (adapted from Field et al. 1993b) combined with Harris' H\&E regressive method (from Luna 1968)

1. Place paraffin sections on slides.

2. Dry slides, deparaffinize and rehydrate.

3. Rinse unstained slides thoroughly with distilled water, and place slides into freshly prepared $1 \%$ sliver nitrate for $30 \mathrm{~min}$ at $37^{\circ} \mathrm{C}$.

4. Wash in distilled water, 3 changes.

5. Place sections in developing solution (see below) in a $60^{\circ} \mathrm{C}$ water bath until the sections turn light brown (i.e. approximately 2 to $3 \mathrm{~min}$ ).

6 . Rinse thoroughly in distilled water. Then rinse in hot running tap water, then rinse in distilled water.

7. Fix sections in $5 \%$ sodium thiosulphate for $3 \mathrm{~min}$

8. Counter stain with Harris' $H \& E$ using the regressive method (Luna 1968). However, decolorize the hematoxylin in acid alcohol $(0.1 \% \mathrm{HCl})$ for $1 \mathrm{~min}$ and stain in eosin for only $15 \mathrm{~s}$.

9. Dehydrate, clear and mount sections.

To minimize background and other staining problems, do not pretreat slides with adhesives, ensure all glassware (including slides) is clean, and use analytical grade reagents.

\section{Reagents}

$1 \%$ Silver nitrate. Dilute $1: 10$ from stock $10 \%$ silver nitrate with acidified water at $\mathrm{pH} 4 . \mathrm{O}$.

Developing solution. Mix $30 \mathrm{ml}$ water, $\mathrm{pH} 4.0$, with $36 \mathrm{ml}$ $5 \%$ gelatin. Preheat above mixture to $60^{\circ} \mathrm{C}$. Add $3 \mathrm{ml} 10 \%$ silver nitrate and $2 \mathrm{ml} 1.5 \%$ quinol immediately before developing. Quinol solution should be no older than $1 \mathrm{wk}$.

Responsible Subject Editor: W. Körting, Hannover, Germany

\section{LITERATURE CITED}

Chilmonczyk S, Cox WT, Hedrick RP (1991) Enterocytozoon salmonis $\mathrm{n}$. sp.: an intranuclear microsporidium from salmonid fish. J Protozool 38:264-269

Elston RA, Kent ML, Harrell LW (1987) An intranuclear microsporidan associated with acute anemia in chinook salmon, Oncorhynchus tshawytscha. J Protozool 34: $274-277$

Field AJ, Hing MC, Milliken ST, Marriott DJ (1993a) Microsporidia in the small intestine of HIV-infected patients: a new diagnostic technique and a new species. Med J Aust 158:390-394

Field AS, Marriott DJ, Hing MC (1993b) The Warthin-Starry stain in the diagnosis of small intestinal microsporidiosis in HIV-infected patients. Folia Parasitol 40: 261-266

Hedrick RP, Groff JM, McDowell TS, Willis M, Cox WT (1990) Hematopoietic intranuclear microsporidian infections with features of leukemia in chinook salmon Oncorhynchus tshawytscha. Dis aquat Org 8:189-197

Kent ML, Groff JM, Traxler GS, Zinkl JG, Bagshaw JW (1990) Plasmacytoid leukemia in seawater reared chinook salmon Oncorhynchus tshawytscha. Dis aquat Org 8: $199-209$

Luna LG (1968) Manual of histologic staining methods, 3rd edn. Armed Forces Institute of Pathology. McGraw-Hill, Toronto

Morrison JK, MacConnell E, Chapman PF, Westgard RL (1990) A microsporidium-induced lymphoblastosis in chinook salmon Oncorhynchus tshawytscha in freshwater. Dis aquat Org 8:99-104

Mullins JE, Powell M, Speare DJ, Cawthorn R (1994) An intranuclear microsporidian in lumpfish Cyclopterus lum. pus. Dis aquat Org 20:7-13

Weber R, Bryan RT, Schwartz DA, Owen RL (1994) Human microsporidial infections. Clin Microbiol Rev 7:426-261

Manuscript first received: February 28, 1995

Revised version accepted: May 9, 1995 